\title{
EFFECTIVENESS OF USING ZOOM MEDIA AS A MEANS OF E-COUNSELING STUDENTS OF GRADE XI MEDICAL LABORATORY ENGINEERING
}

\author{
Url Jurnal: https://uia.e-journal.id/akademika/article/1353 \\ DOI : https://doi.org/10.34005/akademika.v10i01.1353
}

Submitted: 2021-05-03

Moh. Fahri Yasin

Islamic State University

As-Syafi'iyah-Indonesia

mohfachri59@gmail.com
Reviewed: 2021-05-15

Fitri Maulidia

Islamic State University

As-Syafi'iyah-Indonesia

fitriamaulidia1206@gmail.com
Published: 2021-05-30

Iffah Budiningsih

Islamic State University

As-Syafi'iyah-Indonesia iffahbudiningsih@gmail.com

\begin{abstract}
This study aims to describe the effectiveness of application zoom as media e-canceling facilities for class xi students of medical laboratory engineering. This research approach uses descriptive qualitative. The general problem is how far the effectiveness doing canceling using zoom meeting. The specific problem what kinds of problem suitable for student discuss and what kind of zoom fitur using. The subjects in this study were the Headmaster of the Vocational High School (SMK) Bina Husada Mandiri, homeroom teacher students class Medical Laboratory Engineering (TLM) SMK Bina Husada Mandiri, parents of class XI TLM SMK Bina Husada Mandiri, students class XI TLM SMK Bina Husada Mandiri and Counseling Guidance Teachers/ Counselor. The technique of collecting data is use observing the e-counseling process, distributing questionnaires for the effectiveness of application media Zoom, interviews and documentation. The data analysis technique consists of reduction, data exposure and conclusion drawing. there are no paragraphs in the abstract. Based on the findings from interviewing informans, observations, and distributing questionnaires, it is concluded that the e-counseling process with Zoom media in XI grade students of the Medical Laboratory Engineering at SMK Bina Husada Mandiri school. Is efective. The application is carried out once a week, the duration of the counseling is 30 minutes, the Zoom application account uses a personal account. The e-counseling stage consists of three stages, namely pre-counseling (designing and scheduling Zoom), counseling (Activating Zoom room) and post-counseling (making reports and follow-up). Then the effectiveness of Zoom media as a means of E-counseling for class XI students of the Medical Laboratory Technique at the Bina Husada Mandiri Vocational School can be concluded that it is effective as a media of e-counseling, as long as the facilities and infrastructure support and the e-counseling service program implemented is group. Personal and private is limited discussion.
\end{abstract}

Keywords: Effectiveness, Media Zoom, E-Counseling.

\section{INTRODUCTION}

Students are individuals who are given knowledge, guided by their attitudes and behavior, directed in developing their potential through learning in formal and non-formal schools. The purpose of education is to create a generation who has prestation and become individuals with noble character. Factors that influence student achievement are external and internal factors of students. Each teacher also has their respective expertise in educating students. The Counseling Guidance Teacher/counselor have a role, namely helping students develop potential student competencies, social interactions, learning styles, and career planning and 
development. Counseling services provide facilities according to student needs either facilitating students individually or in groups. The guidance and counseling teacher also helps overcome the problems faced by students by providing direction and motivation.

According to the American Counseling Association, counseling helps people make the changes they need, for example the way they think, feel and behave (Husen et al., 2017). The definition of counseling can be grouped into two, namely conventional definition counseling and modern definition counseling (Hartono \& Soedarmadji, 2015). Tolbert's conventional definition counseling quoted by Winkel suggests counseling as face-to-face personal assistance between two people, namely a counselor who is competent in counseling helping someone called a counselee who takes place in a learning situation, so that the counselee can gain a good understanding of himself and an understanding of the situation is present and will come (Prasetyo, 2018). The modern definition of counseling in the counseling process is influenced by technological advances so that the definition of counseling can be interpreted as a counseling profession provided by the counselor to the counselee or group of counselees, where the counseling process is not only given face-to-face, it means that it is not face-to-face because it uses informatics technology such as internet (Hartono \& Soedarmadji, 2015). The term e-counseling comes from the English language, namely e-counseling (electronic counseling) which in short can be defined as the process of organizing counseling electronically (Riswandha \& Maulidyah, 2017).

Ifdil mentions several media that are commonly used, including a) Website/site in conducting online counseling the bk/counselor teacher can provide a website address. So that clients/counselees who want to do online counseling can visit the site especially for further online counseling b) Telephone / Mobile More simply online counseling can be done by using the telephone. c) Email d) Chat. e) Video conferencing, this meeting is assisted by various existing media applications (Ifdil \& Ardi, 2013), video conferencing is a set of interactive telecommunications technology that allows two or more parties in different locations to interact via sending two the direction of audio and video simultaneously in a conference room one of the most popular media at this time is the Zoom Cloud Meeting application (Nazilah et al., 2017). The steps for using the Zoom Cloud Meeting application if using Android are as follows: 1) open the play store; 2) type Zoom Cloud Meeting; 3) click Zoom Us; 4) install or download the application; 5) after downloading, select the Join a Meeting menu; 6) select the Join menu; 7) input Meeting Code/link. 8) the meeting or video conference can be started. Media Zoom is a commonly used video conferencing platform because, in addition to providing good video call quality, features such as a virtual background and a screen display containing the user's face also makes Zoom a video conferencing platform preference for conducting online classes (Noermalia \& Irwansyah, 2020).

The implementation of e-counseling or online counseling must, of course, be carried out effectively, an implementation is said to be effective according to the etymology of the implementation must mean successful or something that is done works well (Zohriah, 2017). The definition of effectiveness according to Gibson is the achievement of agreed goals and objectives to achieve joint business goals. The level of goals and objectives indicates the level of effectiveness and achievement of the goals and objectives will be determined by the level of sacrifice that has been 
made (Riswandha \& Maulidyah, 2017). Then according to steers, effectiveness is a business that becomes a system with certain facilities and resources to meet its objectives and its application does not provide unnatural pressure to achieve goals (Bastaman et al., 2020). As for the criteria or measurement regarding the achievement of effective or not goals, as stated by Sondang, namely, first, the clarity of the objectives to be achieved, this is meant by implementing an implementation or program that is achieved according to clearly directed goals.

The clarity of the strategy for achieving goals, a strategy is a plan to achieve predetermined goals to achieve goals (Johar \& Hanum, 2016). Second, the process of analysis and formulation of solid policies, related to the goals to be achieved and the strategies that have been determined means that policies must be able to bridge these goals with the implementation of operational activities (Syafitri \& Zukarnaini, 2016). Furthermore, the three careful planning. The four proper programmings will result in an application that will achieve the goal. The fifth is the availability of facilities and infrastructure, one of the indicators of effectiveness because it will support the implementation process smoothly. The sixth is effective and efficient implementation, no matter how good a program is, if it is not implemented effectively and efficiently, the implementation of a program will not achieve its target. Finally, the eight systems of supervision and control are educational (Sondang, 2002). Regarding the effectiveness of the implementation of online counseling or ecounseling, several studies are examining the effectiveness of Zoom media as an online counseling medium.

Several previous studies of Haqien and Rahman's research, show that Zoom media is considered ineffective because what often happens is constraints on the network or internet signal for students who do not use wifi which will have an impact on the quality of learning they receive (Haqien \& Rahman, 2020). However, in contrast to the results of research by Monica and Fitriawati, the results of their research show that Zoom media is effective as a learning medium (Monica \& Fitriawati, 2020). Based on the findings of several previous research results, some results show the effectiveness and ineffectiveness of the use of Zoom media as a medium for online counseling or e-counseling. Based on the above explanation, the researcher wants to research under the title Effectiveness of Using Zoom Media as a Means of E-Counseling for Class XI Students of Medical Laboratory Techniques.

\section{METHOD}

This research approach uses qualitative research, the type of research is case study research. The subjects of this study were the Headmaster of the Bina Husada Mandiri Vocational School, Teacher Class XI Medical Laboratory Engineering Bina Husada Mandiri Vocational High School, the parents of the XI Grade Medical Laboratory Engineering Students at Bina Husada Mandiri Vocational High School, Student class XI Medical Laboratory Engineering, Counseling Guidance Teachers / Counselor. The focus of this research is on the effectiveness of the application of Zoom media as a means of E-counseling in class XI students of the Medical Laboratory Technique where the Zoom used is the regular Zoom account with a duration limit of 40 minutes and 100 participants. The data collection techniques used in this study were questionnaires, observations, interviews, and documentation. The data analysis technique consists of three stages, (1) reduction, (2) exposure to data, and (3) 


\section{RESULTS}

School Profile SMK Bina Husada Mandiri, this school was founded in 2010 with a building located on Jl. Mukti Gg.H. Awi RT. 02/04 No.58 Jatiluhur Village, Jatiasih District, Bekasi City, West Java Province. At the beginning of its establishment with rudimentary conditions, SMK Bina Husada Mandiri began running at the beginning of the 2010/2011 academic year. The vision of SMK Bina Husada Mandiri Bekasi is to make SMK Bina Husada Mandiri Bekasi a producer of health workers who are knowledgeable, Islamic, and able to compete in the era of globalization. With the aim of education, namely to produce health workers who have intellectual abilities and skills who apply and develop the repertoire of science and technology. As for the mission of SMK Bina Husada Mandiri, namely 1) Fostering the potential of students in learning activities that are based on Islamic values. 2) Improve participatory management that can create a conducive Islamic atmosphere, and raise awareness in teaching and learning activities as a whole supported by adequate infrastructure. 3) Take an active role in improving the health and welfare of the community in the form of community service based on health science. 4) Make efforts to improve the quality and development of institutions by receiving inputs that lead to positive change. 5) Cooperate cross-sectorally and inter-sectorally at a local, regional and global scale. 6) Explore the potential of the community to jointly improve a healthy lifestyle.

The results of interviews with the principal of SMK Bina Husada Mandiri showed clearly that counseling was carried out online, related to the current rules that schools had not been able to carry out learning activities or counseling at schools, so the principal instructed all teachers to choose the right media for catchup. that's done online. According to the Principal "Zoom meeting is very helpful, because with the existence of e-counseling children are monitored how to learn online in every subject." This expression means that Zoom media can be used as a means of e-counseling and must still run as revealed in the interview. The principal's response was concluded from the results of the interview, Zoom media was effectively used as a means of e-counseling even though there were several obstacles such as those related to the network and internet quota, but for the media it was easy for teachers and students to master in implementing the Zoom application.

The results of interviews with homeroom teachers and counseling teachers showed a good average response related to Zoom media as a means of ecounseling. The homeroom teacher revealed

"Media Zoom is very appropriate to use because during this pandemic there must be counseling even though it is online, e-counseling also runs smoothly. As for the obstacles of some students related to the internet network because there are students who do not have adequate facilities at home. Personal e-counseling is usually carried out outside Zoom, usually students directly chat to whatsapp the teacher to confide in ". The homeroom teacher and counseling teacher's statement regarding Zoom media being used as a means of e-counseling has something in common, namely that Zoom media is very appropriate to be used as a means of $e$ counseling, the existence of an obstacle to Zoom is that the strength of the internet network is lacking because it depends on the signal conditions in the student's place. Then related to the homeroom teacher's statement that when e-counseling was carried out individually outside Zoom, it was strengthened by a statement from the 
counseling teacher, stating "Usually for individual and personal e-counseling, I immediately divert it outside Zoom, namely with Whatsapp, because in Counseling Guidance There is a principle of confidentiality, so for e-counseling using Zoom media is a group service".

Some of the media used by counseling teachers other than Zoom media. Other media include google meet and Whatsapp. Google Meet has the same function as Zoom media, which is both a video conference media. Then the Whatsapp media is used to communicate the e-counseling schedule and the password for Zomm's room. This is reinforced by the statement of the parents of students "The guidance counseling procedure for guidance and counseling using Zoom media, homeroom teachers share links and passwords in the parent group one day before Zooming which previously sent by the counseling teacher to the homeroom teacher". Furthermore, the findings from the interview results showed that Zoom was conducted for 30 minutes for the core of his counseling, meetings were held once a week. Zoom accounts that are owned by students are also their own accounts. Then the supervision of e-counseling during Zoom, parents were not too supervising, but parents knew that there were e-counseling activities using Zoom. The existence of Zoom media makes e-counseling work and after attending ecounseling, students feel that there is a change for the better.

Recordings of-e-counseling using Zoom media as a medium for video conferences in addition to recording results, also researcher observe from cancelling planning done. The result of observation as

Table 1. Observation Sheet of the Effectiveness of Zoom Media as a Means of ECounseling

\begin{tabular}{|c|c|c|c|}
\hline \multirow[t]{2}{*}{ No } & \multirow[t]{2}{*}{ Observation Assessment } & \multicolumn{2}{|c|}{ Evaluation } \\
\hline & & Yes & No \\
\hline 1 & $\begin{array}{l}\text { There is information from Zoom media in the } \\
\text { Guidance and Counseling Service Implementation } \\
\text { Plan (RPLBK) }\end{array}$ & $\sqrt{ }$ & \\
\hline 2 & The teacher conducts E-counseling socialization & $\sqrt{ }$ & \\
\hline 3 & Sound is heard clearly on Zoom media & $\sqrt{ }$ & \\
\hline 4 & Uninterrupted voice during e-counseling & & \\
\hline 5 & $\begin{array}{l}\text { Video conferencing in Zoom smoothly during e- } \\
\text { counseling }\end{array}$ & $\sqrt{ }$ & \\
\hline 6 & Master uses features in the media Zoom & $\sqrt{ }$ & \\
\hline 7 & $\begin{array}{l}\text { Average Students are active in consultation during } \\
\text { the zoom last berlangsung }\end{array}$ & & $\sqrt{ }$ \\
\hline 8 & Many Students do the question privately during zoom & & $\sqrt{ }$ \\
\hline 9 & $\begin{array}{l}\text { All Students orderly in zoom (No noise when teacher } \\
\text { talks) }\end{array}$ & & $\sqrt{ }$ \\
\hline 10 & There are students who actively argue in Zoom during & $\sqrt{ }$ & \\
\hline 11 & The counselor has difficulty using zoom & & $\sqrt{ }$ \\
\hline 12 & Teacher uses break out feature in zoom & & $\sqrt{ }$ \\
\hline 13 & $\begin{array}{l}13 \text { The teacher closes the counseling by giving } \\
\text { conclusions }\end{array}$ & $\sqrt{ }$ & \\
\hline 14 & The counseling teacher gives time for students to ask & $\sqrt{ }$ & \\
\hline
\end{tabular}


No Observation Assessment

Evaluation

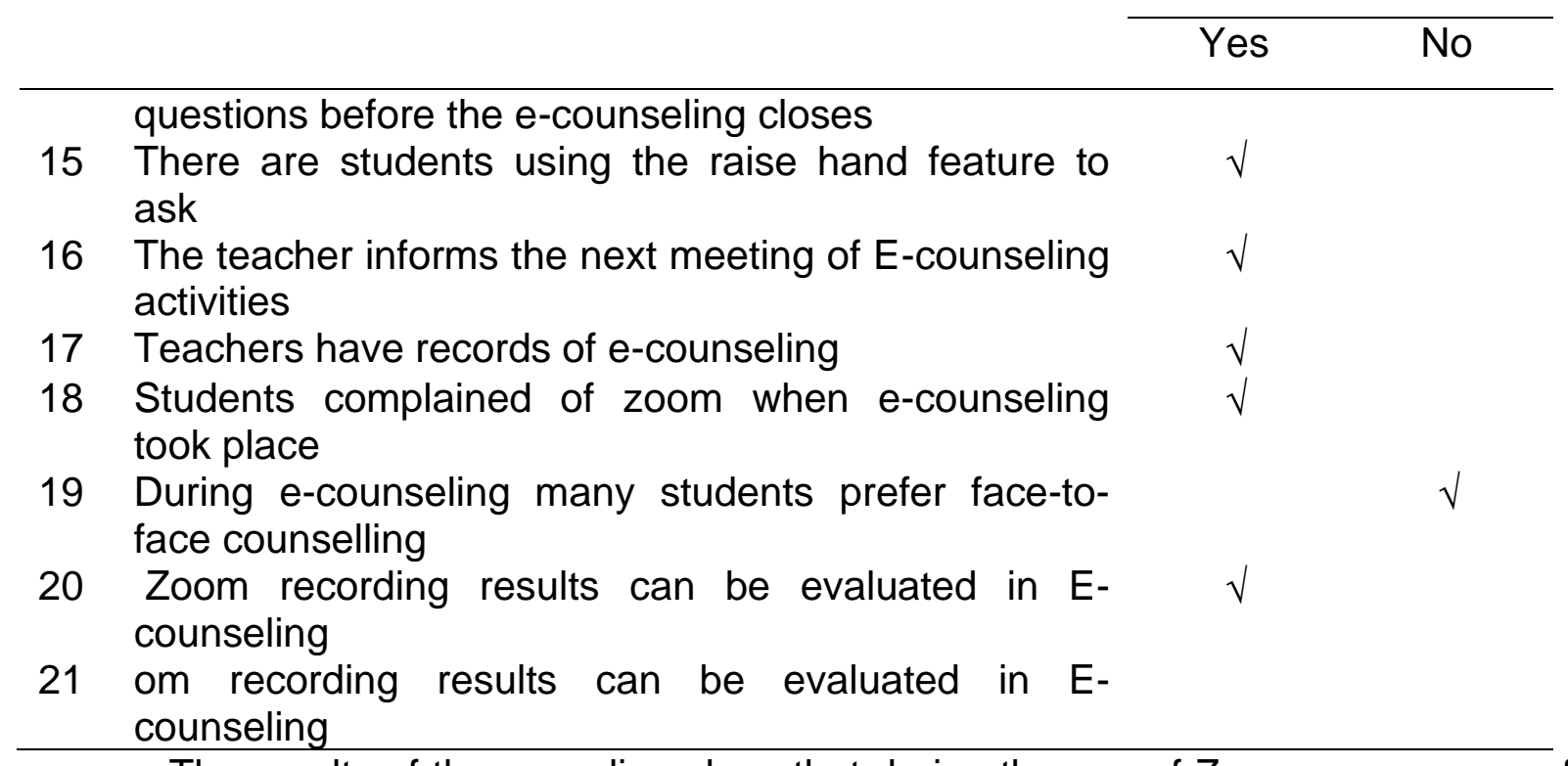

The results of the recording show that during the use of Zoom as a means of e-counseling it can be categorized as running smoothly, although there are some students when the microphone is opened some make a sound, this does not bother other friends who are asking questions. The results of this study are relevant to previous research by Ismawati, her research shows that learning with video conferencing is effective, interactive, and supports distance learning because it is real-time (Ismawati \& Prasetyo, 2020)

\section{DISCUSSION}

The application of Zoom media as a means of e-counseling in class XI majoring in Medical Laboratory Engineering (TLM) SMK Bina Husada Mandiri is carried out once a week, the duration of the counseling lasts 30 minutes. There are three stages of e-counseling, namely pre-counseling, counseling and postcounseling. The application of Zoom media as a means of e-counseling is something that has been done by many other counselors. The spread of the Covid-19 virus outbreak makes the current life situation better for social distancing, therefore counseling at schools is carried out online. The purpose of using the Zoom application media is of course used as a medium for face-to-face conference communication indirectly but at the same time. So the purpose of Zoom media is used so that the counseling continues and provides counseling results that are in accordance with the stated objectives.

The effectiveness of Zoom media as a means of e-counseling in Class XI majoring SMK Bina Husada Mandiri seen from the achievement of the success of e-counseling as a means of channeling messages in the form of interactive telecommunications which allows two or more parties in different locations to interact simultaneously can be measured with clarity. objectives, clarity of strategy, sound process of analysis and policy formulation, careful planning, proper media preparation, availability of facilities and infrastructure, effective and efficient implementation, and a system of monitoring and control of Zoom media.

The clarity of the objectives to be achieved in the results of the research findings found that the targets of the Zoom media were precise and the objectives were clear, this was supported by the findings which indicated that there was 
notification to students regarding e-counseling using Zoom media and the reasons why Zoom media was used, according to the results. The questionnaire in the appendix contained $78.9 \%$ of the guidance and counseling teachers informing the reasons for using Zoom. Based on the results of the interview, all interviewed informants know the purpose of the guidance and counseling teachers using Zoom for e-counseling. So it is clear that the goal is for face-to-face online long distance communication interaction media. The goal is that students continue to do counseling during the learning period from home. According to Atapukang, in his journal, educators or teachers are obliged to design targeted plans so that something that has been planned can run well and the goals that have been formulated can be achieved (Atapukang, 2016) So it can be concluded that in the zoom media the goal is clear as a means of e-counseling. Although there are other media used for ecounseling, these media are to support the smooth running of Zoom.

The clarity of the strategy for achieving goals, the strategy is a plan to achieve predetermined goals to achieve the goal (Johar \& Hanum, 2016) The plan to use Zoom media according to the results of interviews with all informants is appropriate, because the condition of the learning situation from home is due to the covid-19 virus outbreak this supports the use of Zoom media as a means of ecounseling. Based on the results of the questionnaire, $80.9 \%$ of students answered strategy indicators using Zoom media as a means of e-counseling which was appropriate. So it can be concluded from the findings, this indicator supports the effectiveness of Zoom media in this study

The process of analysis and formulation of a solid policy, the purpose of this indicator is related to the goals to be achieved and the strategies that have been determined, meaning that it must be able to bridge the goals with its implementation efforts (Syafitri \& Zukarnaini, 2016). The effort made by the counseling teacher to analyze the use of Media Zoom by asking whether there are any problems with the use of Media Zoom in students. Based on the results of interviews with the counseling teacher who revealed the analysis of the use of zoom media, of course, it was seen from the gaps and needs in the current conditions of online learning. Then the results of a questionnaire regarding this indicator were as much as $67.8 \%$ of the existence of a solid process of analysis and policy formulation. So it can be concluded from the findings, this indicator supports the effectiveness of Zoom media in this study.

Careful planning, what is meant is the guidance and counseling teacher follow-up after conducting e-counseling with Zoom whether in the future it will continue with the same media. Based on the findings in the study, short-term planning, e-counseling was carried out with Zoom media related to the results of interviews with homeroom informants, students, parents and school heads, they said that BK teachers could apply Zoom media without difficulty. Then the results of the questionnaire for this indicator as many as $75 \%$ of students answered that the use of zoom media could be controlled by the counseling teacher. Therefore, BK teachers at SMK Bina Husada Mandiri still use Zoom media at the next e-counseling meeting. So it can be concluded from the findings, this indicator supports the effectiveness of Zoom media in this study.

Appropriate programming is meant as a plan drawn up in accordance with the right conditions. The arrangement of the e-counseling program using Zoom media is not too detailed, because it is seen on the e-counseling service plan sheet, 
because the Counseling Guidance service plan sheet is not too different, it's just that the details of the e-counseling plan are added with media information using Zoom. However, the selection of the media is correct, because from the results of the interviews, the counseling teacher has never used Zoom media for individual ecounseling services, this shows that the counseling teacher applies Zoom media with the target and the e-counseling program is running appropriately. In the results of the questionnaire the percentage of this indicator is $77.3 \%$. So based on the findings related to the proper arrangement of Zoom media, it can support that Zoom media is effective as a means of e-counseling.

The availability of work facilities and infrastructure, means anything that supports the implementation or program being carried out. The results of the interview show that Zoom media is supported by mobile devices such as smartphones, laptops, Zoom accounts. All facilities are owned by class XI students majoring in TLM and BK teachers. However, some of the facilities and infrastructure that the students did not have were internet data. The results of the questionnaire related to the availability of facilities and infrastructure showed that $66.7 \%$ of the percentage of this indicator was the smallest. The results of the questionnaire were also confirmed by the results of interviews which showed that students at the time of e-counseling did not have sufficient internet quota. So it can be concluded that this indicator still supports the effectiveness of Zoom media as a means of e-counseling because the comparison of students who have the facilities and infrastructure that supports it is more.

If a program is not implemented effectively and efficiently, the implementation of a program will not achieve its goals. Media zoom can be effective and efficient as e-counseling advice if all implementation goes well. An effectiveness shows a success in terms of whether the goals and objectives have been achieved or not. If the results of the activity show that it is getting closer to the target, it means the higher the success (Sondang, 2002). The percentage of answers to the questionnaire related to the effectiveness and efficiency of Zoom media is $74 \%$. Then these results are detailed with the results of interviews with counseling teachers who show Zoom media is effective and efficient, but for the condition of individual e-counseling is not effective, this is reinforced by the results of interviews with parents of students. According to him, "To be more efficient together with zoom", in addition to the parents, according to the homeroom teacher, "There is no reason for personal problems, usually students directly whatsapp BK teachers to confide in". Then it was discovered that the time limit for the Zoom application is only 40 minutes for regular accounts, but it is not a problem because the core duration of e-counseling is 30 minutes. Previous research findings are relevant to the results of research which show that Zoom media is effective as a learning medium (Monica \& Fitriawati, 2020).

The supervision and control system, certainly needs to be done because a program or implementation can be achieved and evaluated. Every learning activity or counseling guidance remains under the supervision of the Principal, because the principal is the person who is responsible for the success of education in his school (Manora, 2019). The results of the interview according to the principal of SMK Bina Husada Mandiri revealed

"Zoom media meeting for now is suitable to be used as a media for e-counseling. As for the problem, when Zoom sometimes goes out alone, this may be due to technical 
problems such as internet signal and data, for e-counseling with Zoom media, counseling is discussed which general problems are not personal. ".

The above statement is known to the principal. This indicates that e-counseling is included in the monitoring system. The results of the questionnaire also showed that the parents and the homeroom teacher played a role in monitoring the application of Zoom media as a means of e-counseling. The control of Zoom media by BK teachers, according to informants, BK teachers can control and master the application of Zoom media during e-counseling. Based on the presentation of seven indicators of effectiveness, it shows that all indicators are supportive. Media Zoom as a means of e-counseling can be said to be effective for group e-counseling services. The results of this study are relevant to previous research by Ismawati, her research shows that learning with video conferences is effective, interactive, and supports distance learning because it is real time (Ismawati \& Prasetyo, 2020). less effective because what often happens is the problem with the network or internet signal for students who do not use wifi which will have an impact on the quality of learning they receive. (Haqien \& Rahman, 2020). Although some previous studies have shown relevance to research results and there are previous studies that do not support the research results. The results of this study indicate that the Zoom media is effective as a means of e-counseling as long as the facilities and infrastructure support and the e-counseling service program is a group service.

\section{CONCLUSION}

Based on the results of data collection and analysis, it can be concluded that the first is the e-counseling process with Zoom media for XI grade students of the Medical Laboratory Engineering at the Bina Husada Mandiri Vocational School. The implementation is done once a week for eight zooms with a duration of 30 minutes each using a personal account. The e-counseling stage consists of three stages, namely pre-counseling (designing and scheduling Zoom), counseling (activating Zoom room), and post-counseling (making reports and follow-up). The second is the effectiveness of Zoom media as a means of E-counseling for XI grade students of the Medical Laboratory Engineering at the Bina Husada Mandiri Vocational School because the novelty element of this media is an integrated design of the three stages of e-counseling that combines text, sound, image, and video data. effective as a means of e-counseling, as long as the facilities and infrastructure support and the ecounseling service program implemented is a group service.

\section{REFERENCE}

Bastaman, K., Nawawi, A., \& Taharudin. (2020). Efektivitas Program Desa Migran Produktif (DESMIGRATIF) Pada Dinas Tenaga Kerja dan Transmigrasi Kabupaten Subang. E-Jurnal Unsub, 2(2).

Haqien, D., \& Rahman, A. A. (2020). Pemanfaatan Zoom Meeting untuk Proses Pembelajaran pada Masa Pandemi Covid-19. SAP (Susunan Artikel Pendidikan), 5(1), 51-56. https://doi.org/10.30998/sap.v5i1.6511

Hartono, \& Soedarmadji, B. (2015). Psikologi Konseling. Kencana.

Husen, K., Wardan, N. D., \& Puspitasari, V. D. (2017). Pengaruh Pemberian Konseling Individu Sebelum Melahirkan Terhadap Tingkat Kecemasan Pada lbu Postparrtum. Diponegoro Medical Journal (Jurnal Kedokteran Diponegoro), 6(2), 682-691.

Ifdil, I., \& Ardi, Z. (2013). Konseling Online Sebagai Salah Satu Bentuk Pelayanan E- 
konseling. Jurnal Konseling Dan Pendidikan, 1(1), 15-21. https://doi.org/10.29210/1400

Ismawati, D., \& Prasetyo, I. (2020). Efektivitas Pembelajaran Menggunakan Video Zoom Cloud Meeting pada Anak Usia Dini Era Pandemi Covid-19. Jurnal Obsesi: Jurnal Pendidikan Anak Usia Dini, 5(1), 665. https://doi.org/10.31004/obsesi.v5i1.671

Johar, R., \& Hanum, L. (2016). Strategi Belajar Mengajar. Deepublish.

Monica, J., \& Fitriawati, D. (2020). Efektivitas Penggunaan Aplikasi Zoom Sebagai Media Pembelajaran Online Pada Mahasiswa Saat Pandemi Covid-19. Jurnal Communio: Jurnal Jurusan IImu Komunikasi, 9(2), 1630-1640. https://doi.org/10.35508/jikom.v9i2.2416

Nazilah, D. D., Zakaria, M. N., \& Aisah. (2017). Perencanaan Dan Implementasi Protokol Video Conference Pada Keluarga Narapidana Penghuni Lembaga Pemasyarakatan Menggunakan Smartphone. Jartel: Jurnal Jaringan Telekomunikasi, 4(1), 60-66.

Noermalia, T., \& Irwansyah. (2020). PenerimaanTeknologi Konferensi Video dan Motivasi Belajar. Jurnal Komunikasi, 12(2), 246-262.

Prasetyo, I. (2018). Komunikasi Interpersonal Antara Guru Bimbingan Konseling (BK) Dengan Siswa Dalam Meningkatkan Prestasi Di SMK Negeri 10 Surabaya. Jurnal Ilmu Komunikasi, 1(1), 1-21. https://doi.org/10.33005/jkom.v1i1.16

Riswandha, M. N., \& Maulidyah, N. (2017). Aplikasi E-Counseling Dalam Pemanfaatan Layanan Bimbingan Dan Konseling Untuk Mengatasi Siswa Terisolir Menggunakan Metode Backward Chaining. Jurnal Link, 26(1), 18-23.

Sondang, S. (2002). Kiat Meningkatkan Produktivitas kerja. Rineka Cipta.

Syafitri, Y., \& Zukarnaini. (2016). Efektivitas Strategi Pelaksanaan Belajar Mengajar di SMAN 3 Pekanbaru. JOM FISIP, 3(2), 4.

Zohriah, A. (2017). Efektivitas Pelayanan Perpustakaan Sekolah. Tarbawi, 3(1), 102-110. https://doi.org/http://dx.doi.org/10.32678/tarbawi.v3i01.1782 